\title{
An Organizational and Task Perspective Model Aimed at Enhancing Teachers' Professional Development and Occupational Expertise
}

Citation for published version (APA):

Evers, A., Van der Heijden, B., Kreijns, K., \& Gerrichhauzen, J. (2011). An Organizational and Task Perspective Model Aimed at Enhancing Teachers' Professional Development and Occupational Expertise. Human Resource Development Review, 10(2), 151-179. https://doi.org/10.1177/1534484310397852

DOI:

10.1177/1534484310397852

Document status and date:

Published: 01/06/2011

Document Version:

Peer reviewed version

Please check the document version of this publication:

- A submitted manuscript is the version of the article upon submission and before peer-review. There can be important differences between the submitted version and the official published version of record. People interested in the research are advised to contact the author for the final version of the publication, or visit the DOI to the publisher's website.

- The final author version and the galley proof are versions of the publication after peer review.

- The final published version features the final layout of the paper including the volume, issue and page numbers.

Link to publication

\section{General rights}

Copyright and moral rights for the publications made accessible in the public portal are retained by the authors and/or other copyright owners and it is a condition of accessing publications that users recognise and abide by the legal requirements associated with these rights.

- Users may download and print one copy of any publication from the public portal for the purpose of private study or research.

- You may not further distribute the material or use it for any profit-making activity or commercial gain

- You may freely distribute the URL identifying the publication in the public portal.

If the publication is distributed under the terms of Article $25 \mathrm{fa}$ of the Dutch Copyright Act, indicated by the "Taverne" license above, please follow below link for the End User Agreement:

https://www.ou.nl/taverne-agreement

Take down policy

If you believe that this document breaches copyright please contact us at:

pure-support@ou.nl

providing details and we will investigate your claim.

Downloaded from https://research.ou.nl/ on date: 26 Apr. 2023 


\title{
Full title: An Organizational and Task Perspective Model Aimed at Enhancing Teachers' Professional Development and Occupational Expertise $^{1}$
}

\author{
Arnoud T. Evers, Karel Kreijns \\ Ruud de Moor Centre \\ Open University of the Netherlands \\ Béatrice I. J. M. Van der Heijden
}

Radboud University Nijmegen, Institute for Management Research, Nijmegen, the

\author{
Netherlands \\ Open University of the Netherlands \\ University of Twente, Enschede, the Netherlands \\ John T. G. Gerrichhauzen \\ Ruud de Moor Centre \\ Open University of the Netherlands \\ Future correspondence (corresponding author): \\ Arnoud T. Evers \\ Open University of the Netherlands \\ Valkenburgerweg 177 \\ 6401 DL Heerlen \\ Telephone number: +31-(0)45-5762925 \\ Fax number: +31-(0)45-5762782 \\ E-mail address: arnoud.evers@ou.nl
}

\footnotetext{
${ }^{1}$ See for the article as published online: DOI: $10.1177 / 1534484310397852$. Please refer to this article as: Evers, A. T., Kreijns, K., Van der Heijden, B. I. J. M., \& Gerrichhauzen, J. T. G. (2011). An Organizational and Task Perspective Model Aimed at Enhancing Teachers' Professional Development and Occupational Expertise. Human Resource Development Review, 10(2), 151-179.
} 


\begin{abstract}
Currently, many countries, including the Netherlands, are 'plagued' by severe, both quantitative and qualitative, teacher shortages that are even expected to increase in the years to come. Teachers' occupational development, therefore, has become an important issue on the research agenda of the respective countries. It is essential to develop more thorough insights that enable Human Resource Management (HRM) and Human Resource Development (HRD) professionals in schools to take strategic decisions in developing Teachers' Professional Development (TPD) and Occupational Expertise (OE). The aim of these strategic decisions is to cope effectively with shortages in this occupational sector. In this contribution, we propose a model that focuses on the influence of organizational and task factors on TPD which, in turn, is assumed to enhance OE. We will thoroughly discuss the so-called TPD \& occupational expertise-model, and its implications for research and HRD practice.
\end{abstract}

Keywords: Teachers' Professional Development, Occupational Expertise, Organizational Factors, Task Factors, TPD \& occupational expertise-model 


\section{Introduction}

In the Netherlands, the teaching sector is currently characterized by severe quantitative and qualitative teacher shortages, and the near future will even show an increase in these shortages (Commissie Leraren, 2007). The graying of the teacher population is an important cause of these shortages as many experienced teachers are about to retire. The quantitative shortages in the field increase the risk that unqualified teachers are given more responsibilities than they can cope with, and subsequently, may negatively affect pupils' performance. Recent empirical research has demonstrated that pupil performance indeed largely depends on teacher quality (Cornet, Huizinga, Minne, \& Webbink, 2006) implying that urgent attention is needed in order to respond to this situation. Stimulating the professional development of teachers, being the core issue of this contribution, is an important way of investing in teacher quality (see also Runhaar, 2008).

The contemporary change of our world into a technology-based knowledge society implies an even higher importance of voluntary learning and development of employees across occupational sectors (Maurer, 2002). Life-Long learning, and the necessity of permanent knowledge and competence development of workers in all occupational sectors has been promoted in the EU since the acceptance of the Lisbon agreement (Council, 2000), with teachers being no exception. Teachers have to educate tomorrow's professionals who are expected to be able to cope with the requirements of nowadays' knowledge society (Brandsford, Derry, Berliner, \& Hammerness, 2005; Coonen, 2005; Putnam \& Borko, 2000; Van Eekelen, 2005). In Hoyle and John's (1995) widely cited book entitled 'Professional knowledge and professional practice', the following definition of Teachers' Professional Development (TPD) is used: “The process by which teachers acquire the knowledge, skills and values which will improve the service they provide to clients" (Hoyle \& John, 1995, p. 17), and supports the previously argued need for life-long learning. 
Nowadays, schools have increased autonomy in making strategic decisions, including the ones regarding TPD matters. In the Netherlands, this increased autonomy can be attributed to the way schools are financed since the nineties, that is, based on a system called 'lump sum finance' (Karsten \& Meijer, 1999). Concretely, 'lump sum finance' means that schools receive a budget for a certain period of time, and are less restricted in deciding on the way they spend it, yet, are held more accountable for the results achieved with their budgeting strategy. A demanding set of new roles and challenges in HRM (Human Resource Management) and HRD (Human Resource Development) for schools appears to be the case across many European countries (Pont, Nusche, \& Moorman, 2008). In addition, TPD is not something that is self-evident but has to be carefully designed and implemented by, amongst others, HRM and HRD professionals.

More specifically, to optimize TPD, HRM and HRD professionals need to get a profound insight into factors that influence and possibly stimulate TPD. Therefore, the main goal of this contribution is to develop a model of TPD that informs HRM and HRD professionals in schools, and that can be empirically tested in research. The motive for our interest in an organizational and task perspective is twofold. First, only a few previous studies have been conducted that investigated the effects of organizational and task factors on TPD. Earlier studies have reported on the added value of these factors in the light of professional development regardless of the occupational sector of employees (e.g., Felstead et al., 2005; Van der Heijden, 2003; Van Woerkom, 2003). Therefore we will focus upon these categories of explaining factors within the setting of the teaching profession.

Second, we believe that organizational and task factors are more easily influenced by HRM and HRD professionals, opposed to contextual factors outside the school, like, for instance, legislative mandates. As such, they have, more or less, concrete tools at hand, which can steer their efforts to enhance TPD and OE of the teaching staff. 
Apart from the relationship between organizational and task factors, on the one hand, and TPD, on the other hand, our model will also explore the relationship between TPD and OE. This relationship has been fully described for a variety of professions (Cheetham \& Chivers, 2001), yet, in a very limited sense for the teaching profession. Occupational expertise is a key variable in the light of employees' career development, and determines one's employability (career potential) to a large extent (Van der Heijden, 1998; Van der Heijden, De Lange, Demerouti, \& Van der Heijde, 2009). Grenier and Kehrhahn (2008) stated that it is critical to retain and recruit employees with OE for organizational success to be enhanced. Obviously, an increase in OE also is assumed to add to teacher quality, and herewith to pupil performance.

To systematically investigate the influence of organizational and task factors on TPD and OE, we build on existing work for determining core factors in our model (e.g., Bakker \& Demerouti, 2007; Ellström, 2001; Geijsel, Sleegers, Stoel, \& Krüger, 2009; Kwakman, 1999, 2003; Rosenholtz, Bassler, \& Hoover-Dempsey, 1986; Runhaar, 2008; Sambrook, 2005; Van der Heijden, 2003; Van Woerkom, 2003; Vermeulen, 1997). Most of this previous research has given guidelines for an empirical approach in this field of study (e.g., Ellström, 2001), or have investigated limited models for TPD. However, a comprehensive conceptual model both covering organizational and task factors aimed at stimulating TPD and OE was lacking up to now.

Kwakman $(1999,2003)$ already suggested a research model wherein personal, task, and work environmental factors are related to the professional development of teachers. From her empirical work (2003), she concluded that "participation in professional learning activities depends to a large extent on the personal characteristics of teachers themselves" (p. 167). Notwithstanding its strengths, her model, however, 
incorporates a limited number of work environmental (or organizational) factors, and being aware of this herself, she called for more research in this regard. In a similar vein, the outcomes of the work by Van der Heijden (2003), who studied the direct association between organizational factors and OE, was promising, and may be elaborated on by including a possible mediation effect (with professional development being the mediator).

Summarized, interlacing the two models of Kwakman $(1999,2003)$ and Van der Heijden (2003) leads to a first structure of our baseline conceptual model (see Figure 1). Elaborating on this previous work, we will present a comprehensive model that is assumed to be appropriate for the objective defined in this research. Particularly, among others, the relationship between TPD and OE is made explicit. Moreover, as neither Kwakman (2003) nor Van der Heijden (2003) have distinguished between different organizational levels, based on Bakker and Demerouti (2007) and Vermeulen (1997), we propose to differentiate between four levels of organizational factors: 1) organizational characteristics, 2) structural factors, 3) cultural factors, and 4) factors referring to social-psychological relations. We will discuss these four levels and the relationships between organizational and task factors further on in this contribution (see the section: 'enhancing teachers' professional development and occupational expertise through organizational and task factors').

Subsequently, we will go into an in-depth discussion of the main ingredients of our proposed research model. The article concludes with reflections upon the proposed model, further research, and practical implications.

****INSERT FIGURE 1 ABOUT HERE**** 


\section{Teachers' Professional Development}

In the introduction of this article, we have given a broad definition of TPD as described by Hoyle and John (1995). According to Kwakman (1999, 2003), this definition can be further conceptualized and defined as participation in professional learning activities (such as, training, reading, experimenting, reflecting and, collaborative activities). This definition can be positioned within the framework of the learning participation research tradition (Murphy \& Cross, 2006; Wang \& Wang, 2004). Traditionally, learning took place in more or less formal classroom-based settings. As the transfer of knowledge and skills developed in these settings to workplace settings has appeared to be problematic, the range of possible learning activities has been elaborated by including informal learning activities in the workplace as well, being a typical place where informal learning may occur (Cheetham \& Chivers, 2001; Eraut, 2004; Marsick \& Watkins, 2001; McGuire \& Cseh, 2006). Marsick and Watkins (2001, p. 25) defined informal learning as: “... not typically classroom-based or highly structured, and control of learning rests primarily in the hands of the learner." Similarly, McGuire and Cseh (2006) stressed the importance of workplace learning as an essential component of HRD.

To conclude, we define participation in professional learning activities as both (informal) learning at work and formal learning, like training activities. Although difficulties regarding the transfer of the newly learned to the workplace have been acknowledged (Baldwin \& Ford, 1988), formal learning is still instrumental for providing the highly needed specialist knowledge and theory (Cheetham \& Chivers, 2001), and will be incorporated in our approach.

\section{Occupational Expertise}

Kwakman (2003), already, argued to include the association between TPD, conceptualized as participation in professional learning activities (that is, how one learns 
(Eraut, 2004), and learning outcomes and results (that is, what is learned) in future research. Similarly, Cheetham and Chivers (2001) discussed the possible correlations between particular learning mechanisms, and the development of particular kinds of competence, reflecting the full range of desired skills. Grangeat and Gray (2007) outlined a framework for comprehending teachers' professional competence development, based on conceptions of the collective work of teachers.

According to Van der Heijden (1998, 2000), occupational 'competence' and occupational 'expertise' can be used interchangeably, referring to the personal qualities and capabilities that are needed in the present-day workforce. She reasoned that competence involves not only the ability but also the allocation and acceptance of responsibility in one's job (Van der Heijden, 1998, p. 28). More specific, based on Van der Heijden (2000, 2002) and Van der Heijde and Van der Heijden (2006) we conceptualize the concept of OE as a conglomerate of four aspects: (a) knowledge; (b) meta-cognitive knowledge; (c) skills and (d) social recognition (see Van der Heijde \& Van der Heijden, 2006). Following Alexander, Schallert, and Hare (1991), knowledge consists of declarative knowledge ('knowing that'), procedural knowledge ('knowing how'), and conditional knowledge ('knowing when and where or under what conditions'). Meta-cognitive knowledge, has to do with self-insight or self-consciousness. Skills refers to the particular skills an employee needs to perform qualitatively well, and which are required to be able to fulfill professional tasks. Apart from a high degree of knowledge and skills in a particular professional domain, only in case an employee is socially recognized by important key figures, such as one's supervisor and near colleagues, as someone with a high amount of capabilities, can expertise exist.

Van Woerkom (2003), in a study among employees working in different sectors including agriculture, technical and administration, commercial, economic (see the model in Figure 2), stated that competence and flexibility are highly related. Van Woerkom (2003) 
stated that employees need to be flexibly competent, which means that they have the capacity to both function effectively and efficiently in a profession, and that they can cope effectively with change. This was also argued by Van der Heijden (1996, 2000, 2003). People who are capable of acquiring a strategy to master a new area of expertise or expert performance in another territory can be termed 'flexperts' (Van der Heijden, 1996). Flexperts are people who are both flexible and in possession of expertise. Therefore, we propose to add a flexibility dimension to future studies on the development of teachers' occupational expertise.

\section{****INSERT FIGURE 2 ABOUT HERE****}

The study by Van Woerkom (2003) shows similarities with our baseline conceptual model (as was displayed in Figure 1), although also differences exist. First, the study by Van Woerkom (2003) did not focus specifically on the teaching profession. Second, Van Woerkom incorporated individual factors as well, while our approach comprises an organizational and task perspective. Third, Van Woerkom's study focused on work-related learning, while we focus on TPD, which implies that we investigate both informal learning at work and formal learning. Fourth, Van Woerkom referred to the term work environmental factors instead of organizational factors, which is the terminology we use in our model. We perceive organizational factors to be a broader category than (direct) work environmental factors. Finally, Van Woerkom (2003) did not investigate the relationship between environmental factors and flexible competence.

Current literature on the relationship between influencing factors, on the one hand, and OE, on the other hand, lacks fundamental theoretical frameworks (Van der Heijden, 2003). In a similar vein, Grenier and Kehrhahn (2008) called for more elaborate models of expertise 
that evolve to address employee's working context as well. This context, more specifically, including organizational and task factors, will be thoroughly discussed in the next section.

\section{Enhancing Teachers' Professional Development and Occupational}

\section{Expertise through Organizational and Task Factors}

In this section, we will draw on previous literature in the field of HRM and HRD dealing with relevant organizational and task factors which are assumed to enhance TPD and OE. The aim is to extend the model that has been outlined in Figure 1. The decision to include certain organizational or task factors, in our model, was based on theoretical and empirical grounds. As far as theory is concerned, the socalled Job Demand Resources (JDR) model (Bakker \& Demerouti, 2007; Demerouti, Bakker, Nachreiner, \& Schaufeli, 2001) is important in this regard. The JDR model states that every occupation needs enough job resources in order to enable employees to balance job demands. We hypothesize that, in combination, job demands and job resources can be beneficial for TPD and OE. The JDR model will be explained more elaborately later on in this article. As regards empirical grounds, we searched especially for organizational and task factors that showed a strong empirical relationship with TPD and OE in previous studies. The organizational and task factors that have been found to be relevant will be described in the next sections. We will first describe the relationship between each factor and TPD. Subsequently, we will go into the relationship between each factor and OE. Finally, we will describe the mutual relationships between the organizational and task factors.

\section{Organizational Factors}

We will adhere to the four levels of organizational factors as distinguished in the introduction of this article: 1) organizational characteristics, 2) structural factors, 3) cultural factors, and 4) factors referring to social-psychological relations. However, 
we have to bear in mind that this division is not very strict. For example, cultural factors are related to social-psychological relations as well, and vice versa. Also, structural and cultural factors are mutually related.

\section{Organizational Characteristics}

Organizational characteristics, such as the size of a school, school type, the number of teachers in a school, the composition of staff, and the geographical location, are, in general, assumed not to have a profound impact upon TPD and OE. An exception might be the impact size of a school may have upon the capacity to set up a proper HRM and HRD policy. More concrete, the nature of training and development differs in small organisations compared to large organisations (see also Van der Heijden 2001, 2002). Hill and Stewart (2000) suggested that small and medium-sized enterprises do not have the HRM and HRD expertise, general resources and infrastructure which large organisations more frequently enjoy. Summarized, in order to control for possible influences, size of school is taken into account in our model.

\section{Structural Factors}

The formal differentiation of tasks and authority in an organization constitutes its structure (Creemers \& Sleegers, 2003). Based on Bakker and Demerouti (2007), we position structural factors at the level of the organization at large. Following the definition of structure, we recognize four structural factors that are assumed to be important for the professional development of teachers: 1) organizational facilities, 2) the way the school is organized (the system), 3) guidelines for work, and 4) (age-related) HRM.

As regards the first structural factor, organizational facilities, Van der Heijden (2003, p. 145) referred to the possibilities or availability for employees to learn, and to further develop themselves in the context of their own working organization. Without offering learning opportunities and a sound learning infrastructure (Darling-Hammond, 1998), professional development in any organization will be difficult, if not impossible. Moreover, 
nowadays, in return for life-long investments in learning and strengthening one's employability or career potential (Fugate, Kinicki, \& Ashforth, 2004; Rothwell \& Arnold, Van der Heijde \& Van der Heijden, 2006) (investments which are, more and more, expected to be performed in private time as well), employees expect that organizations offer them opportunities to learn. If not, they will look around for an alternative organization, to the extent their employability enables them to move out, and given sufficient employment opportunities at the labor market. According to Gaspersz and Ott (1996), investing in opportunities to learn, signals an 'excellent employer' image (see also De Grip, Van Loo \& Sanders, 2004).

The amount of investments in HRM and HRD depend on the specific occupational sector. Recently, the educational sector received larger budgets compared to the past for TPD (Commissie Leraren, 2007; Evers, Vermeulen, \& Van der Klink, 2007), implying a promising development for the field aimed at increasing the attractiveness of the profession and the capabilities of current staff to cope with the serious teacher shortages. Van der Heijden (2003) found a significant relationship between organizational facilities and OE (more specifically the dimensions of professional knowledge, and meta-cognitive knowledge) in a study in various business and service sectors. We expect this relationship to hold for teachers too.

Second, the way the school is organized (the system) is important for the (professional) development of teachers. Usually, in a school there are three levels of tasks: 1) the management level, 2) the employees carrying out the teaching work (teachers grouped in departments), and 3) the supporting staff (Vermeulen, 1997). According to Mintzberg (1979), a school can be characterized as a 'professional bureaucracy'. Employees within a 'professional bureaucracy' are, within certain boundaries, autonomous in the performance of their work. Because teachers are, for the greater part of their working time, 'locked up' in 
their classrooms, implying a considerable amount of autonomy, professional isolation might be a risk factor, which may hinder learning from colleagues.

Nowadays, teachers are, more and more, stimulated to work in teams (Commissie Leraren, 2007), implying that the separation between the three task levels (management, teaching and supporting staff) is not that strict anymore. The goal of this team work approach is to work towards a 'collegial organization', wherein teachers are together responsible for the performance of the school. In such an organization, a lot of meetings take place, collaboration in networks is stimulated, and there are many external contacts as well (Vermeulen, 1997). As such, the system or structure of the organization supports the opportunities for collaboration in schools. Also, Scribner (1999) described how school structure could facilitate ongoing collaboration through 'teaming' as well as by means of more subtle adjustments of the organization of teacher work. Stoll, Bolam, McMahon, Wallace, and Thomas (2006) explained how school structures need to be managed to develop professional learning communities and teams.

The way the school is organized probably also influences OE. More specifically, it influences the levels of knowledge and skills that might be built up within the workplace (Ashton, 2004; Lee et al., 2004). In a case study within a multinational corporation, Ashton (2004) found that senior managers had more access to information and knowledge about the organization, and its assets compared with their subordinates. Also, he found that in the investigated organization, which had a power-based hierarchy, there was a considerable amount of control mechanisms governing access to this information and knowledge. Although in schools the power-based hierarchy is probably not that strong, we assume that there is more sharing of information and knowledge in a 'collegial organization' compared to a school with a 'power-based hierarchy'. 
Third, guidelines for work is defined as the extent to which clear guidelines about how to perform one's work are available (Baars-Van Moorsel, 2003; Klarenberg, Van Moorsel, \& Poell, 1996). For example, both the accessibility to regulations and procedures, as well as upto-date information on new developments within the specific field, are essential for employees to be able to perform their work. Clearly stressing employees' responsibilities for learning, as mentioned by Sambrook (2005), can also be seen as a guideline in this respect. The factor 'guidelines for work' is part of the previously developed Learning Climate Questionnaires (Bartram, Foster, Lindley, Brown, \& Nixon, 1993; Mikkelsen \& Grønhaug, 1999). However, one could question whether guidelines for work refer to organizational climate and culture. In our opinion, it is a structural factor. In correspondence with Bartram et al. (1993), and Mikkelsen and Grønhaug (1999), who perceived guidelines for work to be associated with individual learning and personal development at work, we expect that the availability of clear guidelines might enhance TPD and OE.

Fourth, HRM, in particular age-related HRM, is assumed to be important for TPD as well. Research in primary education showed that satisfaction of employees with the HRM policy in their working organization is related to their commitment towards professional learning activities (Evers, Koelink, Teurlings, \& Vermeulen, 1998). Given the current demographic changes, i.e., dejuvenization and ageing of the working population (Shultz \& Adams, 2007), sound age-related HRM policies are important (Ilmarinen, 2005), and should aim for retaining (older) employees for the organization (Pillay, Kelly, \& Tones, 2010; Van Dalen, Henkens, \& Schippers, 2008). In our case, we expect that in a situation wherein older teachers are satisfied with the HRM policy in their school, they will also be more committed to participate in professional learning activities, and probably add more value to their school as well. 
To the best of our knowledge, no previous empirical research has been done on the relationship between the availability of age-related HRM policies and OE. Given the facilitating role the HRM department can play in the light of dissemination of relevant information and knowledge, we expect a positive effect of the availability of age-related HRM policies upon teachers' occupational expertise development. Also, the HRM department could facilitate staff rotation between project teams, herewith enhancing the sharing of knowledge and expertise (Fong \& Chu, 2006).

\section{Cultural Factors}

Culture can be described as a deeper, less consciously held set of cognitions and affective attachments (Mikkelsen \& Grønhaug, 1999; Schein, 1985). Drawing from prior literature, we identify three cultural factors which are believed to be essential for the professional development and occupational expertise of teachers: 1) learning climate, 2) team style, and 3) trust. Based on Bakker and Demerouti (2007), we position these cultural factors at the level of the organization at large.

Climate, being the first cultural factor that has been distinguished, can be comprehended as a direct expression of (an organizational) culture (Schein, 1985). The learning climate within a working organization is important in the light of the actual learning that may occur, and, subsequently, organizational performance (Mikkelsen \& Grønhaug, 1999). Several operationalizations of learning climate exist (e.g., Mikkelsen \& Grønhaug, 1999; Van Woerkom, 2003). We adhere to the operationalization of Van Woerkom (2003), because, to our opinion, by focusing on attachments and values, she comes closest to the definition of culture. She characterized learning climate as the time spent on collective reflection; the amount of contacts between different teams and departments in an organization; learning from the practices of other organizations, and the tolerance towards the different opinions of 'mavericks' (Van Woerkom, 2003). In a study among employees 
working in different sectors, a positive relationship between learning climate and two workrelated learning activities (asking for feedback and reflection) was found (Van Woerkom, 2002). A small negative effect was found for the relationship between learning climate and critical vision sharing, possibly because in a safe climate people are not stimulated to share their visions in a critical way. Given the outcomes of previous research we assume that learning climate is an important predictor of TPD as well.

As regards the relationship between learning climate and occupational expertise of teachers, we expect a positive association. Fong and Chu (2006) stated that enough time (being one aspect of the learning climate) is a critical factor for the sharing of knowledge and experiences. The other aspects of learning climate (the amount of contacts between different teams and departments in an organization, learning from the practices of other organizations, and the tolerance towards the different opinions of 'mavericks'), could also add to what Fong and Chu (2006, p. 938) called a 'knowledge-friendly culture' with ample opportunities for expertise development.

Second, team style indicates perceptions of opportunities to learn from expert colleagues and is a factor that stimulates individual employee's learning (Bartram et al., 1993; Mikkelsen \& Grønhaug, 1999). Van der Heijden et al. (2005) found a positive association between team style and personal flexibility (being an important aspect of OE), among employees working in the IT sector. In line with her empirical work, we expect a positive relationship between team style and OE for teachers as well.

Third, Tschannen-Moran (2001) found a strong significant relationship between the extent of trust in a school and the collaboration among colleagues within the teaching profession. Trust was described as one party's willingness to be vulnerable in the relationship with another party, based on the assurance that the latter party is benevolent, reliable, competent, honest, and open. Collaboration was defined as the degree to which 
commissions/project groups of teachers are involved with, and have influence on, determining professional development needs and goals, and evaluating the curriculum of pupils. The variable trust was operationalized into three dimensions: 1) trust of teachers in colleagues, 2) trust of teachers in the school head, and 3) trust of teachers in parents. Each dimension was positively correlated with the amount of collaboration among colleagues.

Fong and Chu (2006) found that a lack of trust is a barrier for knowledge sharing. Jorgensen (2004) mentioned that in the public sector, trust and a tolerant culture comprise important conditions for learning and sharing knowledge. Although we have not found previous empirical work wherein trust is related directly to the development of the occupational expertise of teachers, we do assume that trust is an important predictor in this regard.

Factors Dealing with Social-Psychological Relations

A social (psychological) relationship is identified as a relationship that is built up through the natural and repeated action and communications among the partners (Sahlstein \& Duck, 2001). Relations are built and sustained by doing through language, discourse and social behavior. Based on the literature, the following factors comprising socialpsychological relations are taken into account in this article: 1) transformational leadership, 2) satisfaction with psychological reward, 3) social support from one's immediate supervisor, and 4) social support from one's close colleagues.

The important role of the leader (or supervisor) in relation to the development of employees (e.g., Van der Heijden, 2003; Van der Heijden \& Bakker, in press; Van Woerkom, 2003), and more specifically teachers (e.g., Creemers \& Sleegers, 2003; Geijsel et al., 2009; Nir \& Bogler, 2008), is discussed in many studies. Especially, the concept of transformational leadership as a predictor of professional development of teachers is very popular in recent works (Geijsel et al., 2009; Runhaar, 2008). In the last decennia, a shift can 
be seen from 'transactional' leadership, wherein the exchange relationship between leaders and employees is important (effort and productivity in exchange for rewards), to 'transformational leadership', which is characterized by leaders having the ability to give a clear vision for the future, to inspire employees, to stimulate employees to develop their talents in the best possible way, and to give their work a deeper meaning (De Hoogh, Den Hartog, \& Koopman, 2004). Runhaar (2008) tested the relationship between transformational leadership and asking feedback, as well as the relationship between transformational leadership and reflection within teachers working in a college for secondary vocational education and training. She found a positive effect of transformational leadership on asking feedback. However, she did not find a significant effect of transformational leadership on reflection. A possible explanation, given by Runhaar (2008), was that asking feedback is an activity teachers do in interaction with each other. On the opposite, reflection is interpreted to be an individual activity, on which situational factors have less influence. Geijsel and colleagues (2009) have found important effects of transformational leadership in primary education as well.

Opposed to De Hoogh et al. (2004), Geijsel and colleagues (2009) operationalized transformational leadership into three dimensions: 1) providing for individual support, 2) providing for intellectual stimulation, and 3) initiating and identifying a vision. Providing individual support had a positive influence on TPD, but this relationship was mediated by other factors. Intellectual stimulation by the leader appeared to have a positive effect on the collaboration of teachers and, through this, on other learning activities as well. Initiating and identifying a vision appeared to have a positive effect on the professional development of teachers.

Except for the work by Van der Heijden and Bakker (in press), who studied the predictive value of transformational leadership in the light of employability (with OE being a 
core ingredient), we have not found previous work that investigated the relationship between transformational leadership and OE. However, past research did look at the relationship between transformational leadership and several employee-related outcomes. For example, Whittington, Goodwin, and Murray (2004) found a direct positive effect of transformational leadership upon subordinate performance (performance defined as quality of work, quantity of work, and promotability) among subjects from twelve different organizations, representing a variety of industries (e.g., manufacturing, governmental agencies and departments, and health care). In a study among ten insurance companies, Tsai, Chen, and Cheng (2009), found, apart from a mediating effect of employee's positive moods, a direct positive effect between transformational leadership and task performance. Van der Heijden (2003) found positive relationships between the attention by one's immediate supervisor for a broader career development, being an important aspect of transformational leadership, and several dimensions of OE.

Also, for teachers, the role of transformational leadership in the light of several outcome variables has been studied. In a high school, Krishnan (2005) found positive relationships between transformational leadership and terminal congruence (defined as the extent of agreement between the leader's and the follower's value system, identification with the organization, and attachment and commitment to the organization). In a meta-analysis on the impact of transformational school leadership on school outcomes in Taiwan and the USA, Chin (2007) found significant and positive direct effects of transformational leadership on job satisfaction, and perceived school effectiveness. To conclude, given the outcomes of previous research on the added value of transformational leadership, we expect a positive influence on teachers' occupational expertise as well.

A second factor within the category of social (psychological) relations is the degree of satisfaction of employees who received a psychological reward from their supervisor (e.g., a 
compliment, or a word of thanks). According to De Gieter (2008), this factor may be explained as supportive and positively evaluated outcomes of the professional interpersonal relationship an employee develops with his or her supervisor. De Gieter (2008) described the relationship between satisfaction with a psychological reward and the behavior of employees. Although only the relationship between satisfaction with a psychological reward and the intention to leave the organization was proven in De Gieter's research (2008), she argued to expect a positive effect upon employees' performance as well, and called for more empirical work in this regard. Probably, because the concept of psychological reward satisfaction is a relatively new concept, we have not found other research that investigated the relationship between psychological reward satisfaction, TPD, and OE. We assume a significantly positive relationship between psychological reward satisfaction, TPD and OE, as these last two concepts can be interpreted to be, respectively, behavioral and performance outcome variables.

The third and fourth social (psychological) factor, which is assumed to be important for the development of teachers, comprises social support from one's immediate supervisor and social support from one's close colleagues (e.g., Ashton, 2004; Blokhuis, 2006; Eraut, 2007; Felstead et al., 2005; Van der Heijden, 2003; Wang \& Wang, 2004). Although, based on a thorough literature study, social support was initially categorized by De Gieter as a psychological reward, after qualitative and quantitative analyses, she argued that it should not be perceived as part of psychological reward.

Social support is an important ingredient of the JDCS model (Job Demands Control Support model). In 1990, the JDC model (which is more elaborately explained under the next section entitled 'task factors') was extended with the factor social support (S); herewith launching the so-called JDCS model (Karasek \& Theorell, 1990). Karasek and Theorell (1990) characterized social support as the overall levels of helpful social interaction available 
on the job. Social support can be delivered by both colleagues and management (school leaders).

In accordance with Bergers, Marcelissen, and De Wolff (1986), Kwakman (2001, 2003) focused on two functions of social support for teachers. The first function is instrumental with the support being oriented towards the accomplishment of tasks. The second function is emotional with the support being oriented towards the emotional aspects of accomplishing the task, and refers to "the degree to which a person's basic emotional need to solve problems at work are gratified through interaction with others" (Brouwers, Evers, \& Tomic, 2001, p. 1475). Emotional support may also enhance one's self-esteem, and is very important in the light of one's future development (Van der Heijden, 1998).

Kwakman (2003) found a positive relationship between collegial support and instructional learning activities. In an empirical study among employees working in several occupations (e.g., managers and senior officials, professionals, associate technical staff, administrative and secretarial staff, skilled trades and personal service staff), Felstead et al. (2005), stressed the importance of line management support for learning. Blokhuis (2006) mentioned the importance of managers for employees who are enabled to learn on the job.

Van der Heijden (2003) studied the relationship between social support from one's immediate supervisor, and social support from one's close colleagues, on the one hand, and OE, on the other hand. In line with House (1981), next to instrumental and emotional support [the two types of support that Kwakman (2003) used], Van der Heijden (2003) operationalized social support as comprising two more functions, namely appraisal support, and informational support (see also Peeters \& Le Blanc, 2001). Appraisal support entails the transmission of information that is relevant to self-evaluation. Informational support assists individuals to help themselves so that they are able to proceed with their tasks. It may include a variety of practical help. The outcomes of Van der Heijden's (2003) research indicated that 
social support from one's immediate supervisor plays a significant role with regard to OE (more specifically with regard to the further development of professional skills and one's growth potential). Although, she did not find a significant effect of support by close colleagues, she called for more research in this field in order to enable researchers to more safely conclude on possible causes for this outcome. She hypothesized that it might be that in higher level jobs, wherein employees work highly independently, colleagues might often not be in a position to provide each other with constructive feedback. In an alternative explanation she came up with the idea that it could be that employees attach greater value to the feedback and support from their immediate supervisor. Obviously, more research is needed to better understand the contribution of social support from both parties, also for teachers.

\section{Task Factors}

Task factors play a central role in teachers' professional development. Two important models that incorporate task factors are the Job Demand Control (JDC) model (Karasek, 1979), and the Job Demand Resources (JDR) model that builds upon the JDC model (Demerouti et al., 2001). Job demands are defined as "Stress sources (stressors), such as work load demands, present in the work environment" (Karasek, 1979, p. 287). Job control is defined as "decision latitude" (Karasek, 1979, p. 287). It refers to the opportunity to act autonomously and independently within the job, and to exercise influence over decisions regarding working conditions and organizational issues (Karasek \& Theorell, 1990). According to Karasek (1979), the amount of balance between job demands and the amount of control employees have in their work determine the amount of stress they experience. Moreover, this balance determines the extent to which a job is 'active', which is hypothesized to lead to the development of new behavioral patterns, being learning.

The JDR model states that every occupation has job demands (such as pressure of work and emotional demands) and job resources (like social support and autonomy, to 
mention but a few). Job demands are not per definition negative, but they need to be compensated with job resources (Bakker \& Demerouti, 2007). As stated by Bakker and Demerouti (2007), job resources not only comprise control or decision latitude, like in the JDC model, but may also refer to other resources at the level of the task and organization of work, at the level of social relations, or at the level of the organization at large.

De Jonge and Dormann (2003) explicitly link job demands and job resources directly to active learning and growth which originates when 'arousal', caused by a job demand, is changed in the direction of a direct efficient action by the application of a specific and matching resource. This comprehends an important theoretical argument supporting our choice to link the modeled organizational and task factors, as explained in this article, to participation in professional learning activities, and OE. We will first discuss two task demand factors: work pressure and emotional demands, followed by three task resources' factors: participation in decision making, autonomy, and the learning value of the function.

In the JDR model, job demands refer to a high work pressure, emotionally demanding interactions with clients, and unfavorable high amount of physical demands (Bakker \& Demerouti, 2007). For teachers, it seems that especially work pressure and emotional demands are characteristic for every day work practice. Physical demands are, for example, an important work characteristic for nurses (De Jonge, Mulder, \& Nijhuis, 1993; Van der Heijden, Demerouti, Bakker, \& Hasselhorn, 2008; Van Vegchel, De Jonge, Meijer, \& Hamers, 2001), but less for teachers, as their work does not include physical labor.

Work pressure is defined as "... quantitative demanding aspects such as the pace of work and workload" (Kwakman, 2003, p. 161). In a study among machine operators and office technicians who were newcomers to their job, Taris and Feij (2004) found high levels of learning in jobs with a combination of high demand (in terms of time pressure) and high control, and low levels of learning in jobs with a combination of low demand and low 
control. In their research, learning was defined as the degree to which one engages in learning activities as well as skill development (being an important aspect of OE). Kwakman (2001) found similar interaction effects for teachers in secondary education, although she concluded that job demands and job control are better suited for explaining stress than for explaining participation in learning. Kwakman (2003) also found a direct positive significant effect of work pressure on participation of teachers in two types of TPD: collaborative activities and instructional activities. Additional research is necessary to find out whether demands impact TPD and OE by means of direct and/or interaction effects.

Emotional demands refer to "... the extent to which the teaching job requires emotional investment” (Kwakman, 2003, p. 161). Taris and Schreurs (2009), in a study among home care employees, reported a significant interaction effect between emotional demands and control upon learning behavior. In their study, learning was defined as the degree to which employees indicate that they learn new behavior patterns and skills, which is close to our definition of TPD and OE. High levels of emotional demands were conducive for learning, but only if job control was high. When control was low, high emotional demands were associated with relatively low levels of learning. Similar interaction effects have been found for teachers in secondary education (Kwakman, 2001). Taris and Schreurs (2009) did not find a direct effect of emotional demands upon learning behavior. Kwakman (2003) instead, found a direct positive effect of emotional demands on three types of TPD: collaborative activities, individual activities and instructional activities. Again more research is needed to more safely conclude whether demands influence TPD and OE by means of direct and/or interaction effects.

In the JDC model, participation in decision making is a factor that refers to the amount of control employees have, herewith being an important resource. Participation in 
decision making refers to.... "the influence a worker has over the working environment and the opportunities to take part in decision making..." (Kwakman, 2003, p. 161).

Rosenholtz et al. (1986) studied teachers in primary education and found a significant positive effect of participation in decision making (in this case as regards instructional matters) and a specific type of TPD: teacher collaboration (assisting each other with information on teaching). Creemers and Sleegers (2003, p. 134) stated that participation in decision making has a positive influence on teachers' learning, provided that this is focused on educational and teaching policy of the school, and not on conditions and organizational aspects (like HRM policy, teachers'schedules, and finances). Geijsel, Sleegers, Van den Berg, and Kelchtermans (2001) discovered a significant positive relationship between participation in decision making and TPD (operationalized as keeping abreast of new developments, experimentation in teaching practices, and reflection). Furthermore, participation in decision making is seen as a resource in the JDR model, and as such influences personal growth, learning and development (Bakker \& Demerouti, 2007). Autonomy is another factor that is essential in the light of learning and growth of employees (Jorgensen, 2004) and teachers (Hoekstra, 2007; Kwakman, 1998, 2003), and refers to ... "the opportunity of the teacher to determine different task-related characteristics ...” (Kwakman, 2003, p. 161). Kwakman (1998) found a direct effect of autonomy upon cooperative activities: teachers with high scores on autonomy participated more in cooperative activities, in comparison with teachers with moderate and low scores on autonomy. Autonomy, being a job resource, is also assumed to stimulate personal growth, learning and development (Bakker \& Demerouti, 2007).

The last task factor that is incorporated in our model comprises the learning value of the function for the employee him or herself (Van der Heijden, 1998; Van der Heijden et al., 2005) and is defined as "the value which the function has as a nutrient for the employee's 
further professional development" (Boerlijst, Van der Heijden, \& Van Assen, 1993, p. 57). Van der Heijden (1998) found a positive relationship between the learning value of the function and the degree of professional knowledge, among employees working in a variety of occupational fields. In a study among IT professionals (Van der Heijden et al., 2005), learning value appeared to be positively associated with personal flexibility (an important aspect of OE) as well. Moreover, Van der Heijden and Bakker (in press) found a positive contribution of the learning value of one's job in the light of one's employability (or career potential). Given the outcomes of previous research, we expect the learning value of the job to be a positive predictor for teachers' further professional development and growth in expertise.

\section{Relationships between Organizational and Task Factors}

Until now, we have discussed the relationships between organizational and task factors, on the one hand, and TPD and OE, on the other hand. Moreover, we have discussed some relationships between different organizational factors (e.g., the relationship between satisfaction with psychological reward and social support), and relationships between different task factors (e.g., between job demands and job resources). Although, possibly, more relationships between factors within the same category (be it organizational or task factors) may be hypothesized, it is not our intention to elaborately describe them in this article. Our interest lies in the relationship between organizational and task factors.

First, based on Bakker and Demerouti (2007), we argue that all organizational factors in our model may act as job resources aimed at coping with the distinguished job demands: work pressure and emotional demands. As previously stated, active learning and growth are stimulated when 'arousal', caused by a job demand, is changed in the direction of a direct efficient (learning) action, by means of the application of a specific and matching resource. An example of this is a job which has a combination of high demands (work pressure and 
emotional demands), but at the same time appropriate organizational facilities; or a job with high demands and a good learning climate. Likewise, a job with high demands but positioned in an organization where transformational leadership is present, might enable a teacher to cope, learn and even to grow in terms of expertise.

Besides work pressure and emotional demands, relationships between the other three task factors and the organizational factors could be present too. For example, structural factors, more specifically, the way the school is organized, can influence the amount of autonomy, and the extent to which teachers participate in decision making in their specific school. For instance, in schools wherein a team structure has been implemented, teachers will lose part of their autonomy, but they will probably participate more in decision making. The guidelines for work could also (negatively) influence how much autonomy teachers experience. For example, nowadays, educational policy in the United Kingdom is linked to wider social and political movements, and towards more accountability and performance management, which, obviously, largely constrains a teacher's freedom (Hodkinson \& Hodkinson, 2003). Also, in the Netherlands, we observe a trend that through organizational principles, such as standardization and specialization, teachers' autonomy is possibly decreasing (Martens, 2009).

The factors transformational leadership, social support from one's immediate supervisor, and social support from one's close colleagues, could influence the amount of learning value of the function. A supervisor and colleagues can support, inspire, and stimulate teachers to develop their talents in the best possible way, and may give their work a deeper meaning. This may lead to a function which is experienced as a nutrient for developing new knowledge and skills.

The relationships as discussed so far are summarized in Figure 3. 
****INSERT FIGURE 3 ABOUT HERE****

\section{Discussion}

\section{Reflections upon the proposed model}

McGuire and Cseh (2006), in a Delphi study among HRD experts, stressed the importance of understanding learning concepts in applying the principles of HRD. Poell, Van Dam and Van den Berg (2004) stated that individual learning has to be researched in relation to its various contexts, that is, in relation to job and task characteristics, in interaction with employees, managers, and HRD professionals in the workplace, and within the broader learning culture, and climate of the organization. Our goal of this article is to give HRM and HRD professionals in schools and researchers an overview of the most relevant organizational and task factors for teachers' professional development (TPD), defined as participation in professional learning activities, and the subsequent development of occupational expertise $(\mathrm{OE})$.

The pioneering work of Kwakman $(1999,2003)$ gave us a good starting-point in this regard, as she has studied a model wherein personal, task, and work environmental factors were related to the professional development of teachers. However, she studied a limited number of work environmental or organizational factors and called for more research including more specific factors in this regard. Van der Heijden (2003) has studied the relationship between organizational factors and OE. Interlacing her model with Kwakman's model led to our newly developed integrated baseline conceptual model (see Figure 1). Based on theoretical and empirical grounds, we included certain organizational and task factors and developed the so-called TPD \& occupational expertise-model (see Figure 3).

Previous research models in the educational domain, although very valuable in its own right, only investigated parts of our proposed model. For example, Rosenholtz et al. (1986) 
limited themselves to the relationship between organizational conditions and teacher collaboration, and did not go into other TPD activities. Moreover, as regards the organizational factors, most previous studies investigated the impact of a limited amount of these factors as predictors of professional learning (e.g., Kwakman, 2003; Runhaar, 2008). Other studies focused on the direct relationship between organizational factors and the effectiveness of schools, reflected in organizational effectiveness and student learning (Johnson \& Stevens, 2006; Loup, 1997).

In addition, some researchers studied the influence of several predictors on professional learning; yet they did not incorporate the effects these predictors may have on OE (e.g., Geijsel et al., 2009; Hodkinson \& Hodkinson, 2003; Hodkinson \& Hodkinson, 2005). To be specific, Geijsel et al. (2009) dealt with the relationship between organizational and task conditions, on the one hand, and TPD, on the other hand, yet, did not include the impact upon OE. Similarly, Hodkinson and Hodkinson (2003, 2005) also focused on the organizational and policy context of teachers' learning, and not on the effect of teachers' learning on $\mathrm{OE}$.

Outside the educational domain, the only model that comes close to our model is the one developed by Van Woerkom (2003). However, her model was developed (job) domain independent, and not specifically for teachers, herewith necessitating cross-validation within the teaching sector. In our opinion, future theories should take a more comprehensive view on the organizational (organizational characteristics, structural, cultural, and social-psychological relations) and task factors (work pressure, emotional demands, participation in decision making, autonomy and learning value of the function) influencing TPD and OE, as discussed in this article. In this way, it will also become more clear how factors may be interrelated.

In addition, from a theoretical point of view, until now, studies that apply the Job Demand Resources framework in research aimed at predicting TPD and OE are lacking. 
Previous research has indicated the validity of the JDR model in the light of predicting employee health and well-being (e.g., De Jonge, Le Blanc, Peeters, \& Noordam, 2008; Demerouti et al., 2001; Van der Heijden, Demerouti, Bakker, \& Hasselhorn, 2008). Empirical work using the model as proposed in this contribution may provide more insight into the applicability of the JDR framework. As job demands and job resources are directly linked to active learning and growth (De Jonge \& Dormann, 2003), it is highly important to seriously pay attention to close this gap in the literature. Active learning and growth originate when 'arousal', caused by a job demand, is changed in the direction of a direct efficient (learning) action, by means of the use of a specific and matching resource. Moreover, although we focused on teachers, our model may inspire research in other professions as well, leading to more knowledge about its generalizability.

\section{Further Research}

A preliminary study by Evers, Reynders, and Janssen (2008), who investigated the face validity of our research, already supported some of the relationships in our proposed TPD \& occupational expertise-model. More specifically, six directors from secondary schools recognized and supported the relevance of the organizational factors distinguished by Van der Heijden (2003) (organizational facilities, social support from one's close colleagues, social support from one's immediate supervisor, and the attention by one's immediate supervisor for a broader career development). Obviously, future research using large-scale quantitative survey research is necessary in order to validate our proposed TPD \& occupational expertisemodel.

Quantitative survey research may reveal elaborate insights as regards the strength of the direct effects of the distinguished organizational and task factors on OE. However, although previous researchers correctly pointed that these direct effects may exist, we hypothesize that TPD activities mediate the relationship between these factors and OE. We 
argue that building up new knowledge and skills, personal flexibility, and reputation among important key figures, that is social recognition (all being important aspects of $\mathrm{OE}$ ), requires that a reasonable amount of time is spent on incorporating, experimenting, and processing the newly learnt in daily work practice.

For example, experimenting with new teaching methods and reflection on strong and weak points will lead to new knowledge, skills, and personal flexibility. Also, organizational and task factors have probably more potential to influence TPD than OE, because TPD activities can be organized more easily. In Figure 4, we have dotted the direct effects of the organizational and task factors on $\mathrm{OE}$, to visualize our expectation of possible mediation effects.

It is also important to test possible moderation effects. Our research model gives ample opportunities in this regard, not only in terms of possible effects of interaction with age and gender, to mention but a few demographic factors (Griffiths, 1997). Future empirical studies should at least control for demographic factors. As previously explained, also possible interaction effects (e.g. based on the JDR theory) between model variables need to be further investigated.

****INSERT FIGURE 4 ABOUT HERE****

\section{Practical Implications}

A key stone in HRM and HRD policy in schools concerns the professional development of teachers (TPD). Knowing more about which organizational and task factors in schools contribute to TPD, could help school directors and HRD professionals to better guide the development of teachers' expertise. The conceptual framework that has been proposed in this article can be used as a research tool to investigate the organization and task environment 
in schools, in order to detect stimulating (or hindering) factors in the light of teachers' further professional development. With this information specific interventions and actions can be implemented in teachers' work practice.

For example, in case a school is too small to have enough HRM and HRD expertise, general resources, and a sound infrastructure to set up proper TPD activities, improvements may be implemented, for instance by means of a merger with another school. Of course, there is a risk of having too large schools, because these cause more bureaucracy and distance between teachers, HRD professionals, and school directors. In that case, its physical structure could be changed (e.g., by creating larger classrooms where teachers can teach and learn together). Also, its hierarchical structure could be changed (e.g., by introducing team work, or by flattening the organization).

Research using our TPD \& occupational expertise-model could indicate that a school's learning climate is not optimal. In particular, there might be a serious lack of tolerance for the different opinions of the teachers in a school. As tolerance is an important aspect of learning climate and a serious condition for learning to take place, it is important to change a culture that lacks tolerance, for example, by organizing brainstorm sessions where every opinion counts, and is actually appreciated. School directors are key figures in a process aimed at changing such a culture, by really listening to what each teacher has to say.

Also, if research using our model demonstrates that the social support from supervisors is low, specific action, such as supervisory training is needed in order to optimize the situation, and to enable TPD and OE enhancement. Supervisors ought to seriously invest in all four functions of social support: 1) instrumental support, intended at the achievement of concrete tasks; 2) emotional support, which helps to enhance teachers' self-esteem; 3) appraisal support, referring to information important to self-evaluation; and 4) informational 
support, which helps teachers to assist themselves (House, 1981; Peeters \& Le Blanc, 2001; Van der Heijden, 2003).

Finally, our conceptual framework shows that job demands (e.g., work pressure) can work beneficial for TPD and OE, yet only, in case enough resources are available in order to buffer these demands. The set of organizational factors that have been dealt with in this contribution (i.e., organizational characteristics, structural, cultural and social-psychological relations) and task factors (i.e., participation in decision making, autonomy, and the learning value of the function), can function as resources. Moreover, it is important to constantly monitor the balance between demands and resources for teachers in schools.

Sound organizational and task conditions, and constructive Human Resource policies are essential, because, nowadays, schools have gained more autonomy for making strategic decisions, including HRM and HRD matters due to the system of 'lump sum finance' (Karsten \& Meijer, 1999). Proper school policies as regards TPD will add to teachers' occupational expertise, and as a consequence, to the quality of teachers. An increase in the quality of teachers will not only lead to an increase in status of the teaching profession, but also to a better pupil performance (Cornet et al., 2006). This will hopefully entail that more young talented people become a teacher, herewith responding to the urgent need for more professionals in the field. 


\section{References}

Alexander, P. A., Schallert, D. L., \& Hare, V. C. (1991). Coming to terms: How researchers in learning and literacy talk about knowledge. Review of Educational Research, 61(3), 315-344.

Ashton, D. N. (2004). The impact of organizational structure and practices on learning in the workplace. International Journal of Training and Development, 8(1), 43-53.

Baars-van Moorsel, M. (2003). Leerklimaat. De culturele dimensie van leren in organisaties [Learning climate. The cultural dimension of learning in organizations]. Doctoral dissertation, Delft: Eburon.

Bakker, A. B., \& Demerouti, E. (2007). The Job Demands-Resources model: state of the art. Journal of Managerial Psychology, 22(2), 309-328.

Baldwin, T. T., \& Ford, J. K. (1988). Transfer of training: a review and directions for future research. Personnel Psychology, 41(1), 63-105.

Bartram, D., Foster, J., Lindley, P. A., Brown, A. J., \& Nixon, S. (1993). Learning climate questionnaire (LCQ): Background and technical information. Oxford: Employment Service and Newland Park Associates Limited.

Bergers, G. P. A., Marcelissen, F. H. G., \& de Wolff, Ch. J. (1986). Vragenlijst Organisatie Stress-D (VOS-D) [Questionnaire organizational stress]. Nijmegen: University of Nijmegen. 
Blokhuis, F. T. L. (2006). Evidence-based design of workplace learning. Doctoral dissertation, Twente, University of Twente.

Boerlijst, J. G., Van der Heijden, B. I. J. M., \& Van Assen, A. (1993). Veertig-plussers in de onderneming [Over-forties in the organization]. Assen: Van Gorcum/Stichting Management Studies.

Brandsford, J., Derry, S., Berliner, D., \& Hammerness, K. (2005). Theories of learning and their role in teaching. In L. Darling-Hammond \& J. Bransford (Eds.), Preparing teachers for a changing world (pp. 40-87). San Fransisco, CA: Jossey-Bass.

Brouwers, A., Evers, W. J. G., \& Tomic, W. (2001). Self-efficacy in eliciting social support and burnout among secondary-school teachers. Journal of Applied Social Psychology, 32(7), $1474-1491$.

Cheetham, G., \& Chivers, G. (2001). How professionals learn in practice: an investigation of informal learning amongst people working in professions. Journal of European Industrial Training, 25(5), 248-292.

Chin, J. M. (2007). Meta-analysis of transformational school leadership effects on school outcomes in Taiwan and the USA. Asia Pacific Education Review, 8(2), 166-177.

Commissie Leraren [Dutch Teacher Commission] (2007). Leerkracht! [Teacher!]. Den Haag: DeltaHage. 
Coonen, H. (2005). De leraar in de kennissamenleving [The teacher in the knowledge society]. Inaugural address. Heerlen: Open University of the Netherlands. Retrieved February 2, 2010, from http://www.ou.nl/Docs/Expertise/RdMC/Oratie_Hubert_Coonen.pdf.

Cornet, M., Huizinga, F., Minne, B., \& Webbink, D. (2006). Kansrijkkennisbeleid (Report No. 124). Den Haag: Centraal Planbureau.

Council (2000). Presidency Conclusions, Lisbon European Council (23 and 24 March 2000). Available online at: http://ue.eu.int/ueDocs/cms_Data/docs/pressData/en/ec/00100-r1.en0. Htm.

Creemers, B., \& Sleegers, P. (2003). De school als organisatie [The school as organization]. In N. Verloop \& J. Lowyck (Eds.), Onderwijskunde (pp. 113-148). Groningen/Houten: WoltersNoordhoff.

Darling-Hammond, L. (1998).Teacher learning that supports student learning. Educational Leadership, 55(5), 6-11.

De Gieter, S. (2008). The multi-dimensionality of reward satisfaction: empirical studies in profit and non-profit organizations. Doctoral dissertation, Brussel: Vrije Universiteit Brussel.

De Grip, A., Van Loo, J., \& Sanders, J. (2004). The industry Employability Index: Taking account of supply and demand characteristics. International Labor Review, 43(3), 211-233. 
De Hoogh, A. H. B., Den Hartog, D. N., \& Koopman, P. L. (2004). De ontwikkeling van de CLIO: een vragenlijst voor charismatisch leiderschap in organisaties [The development of the CLIO: a questionnaire for charismatic leadership in organizations]. Gedrag \& Organisatie, 17, 354382.

De Jonge, J., \& Dormann, C. (2003). The DISC model: Demand-induced strain compensation mechanisms in job stress. In M. F. Dollard, H. R. Winefield \& A. H. Winefield (Eds.), Occupational stress in the service professions (pp. 43-74). Londen: Taylor \& Francis.

De Jonge, J., Le Blanc, P. M., Peeters, M. C. W., Noordam, H. (2008). Emotional job demands and the role of matching job resources: a cross-sectional survey study among health care workers. International Journal of Nursing Studies, 45, 1460-1469.

De Jonge, J., Mulder, M. J. G. P., \& Nijhuis, F. J. N. (1993). The incorporation of different demand concepts in the Job Demand-Control model: effects on health care professionals. Social Science and Medicine, 48, 1149-1160.

Demerouti, E., Bakker, A. B., Nachreiner, F. and Schaufeli, W. B. (2001). The job demandsresources model of burnout. Journal of Applied Psychology, 86, 499-512.

Ellström, P-E. (2001). Integrating learning and work: problems and prospects. Human Resource Development Quarterly, 12(4), 421-435.

Eraut, M. (2004). Informal learning in the workplace. Studies in Continuing Education, 26(2), 247273. 
Eraut, M. (2007). Learning from other people in the workplace. Oxford Review of Education, 33(4), 403-422.

Evers, A., Reynders, L., \& Janssen, S. (2008). Het karakter en de ambities van de Academische School Limburg. Professionaliseren van binnenuit [The character and the ambitions of the Academic School Limburg. Professional development from inside out.]. Heerlen: Open University of the Netherlands.

Evers, A., Vermeulen, M., \& Van der Klink, M. (2007). The need to invest in teachers and teacher education: How to manage costs and achieve quality in teacher education? Heerlen: Open University of the Netherlands.

Evers, G. H. M., Koelink. N., Teurlings, C. C. J., \& Vermeulen, M. (1998). HRM modellen in het primair onderwijs [HRM models in primary education]. Tilburg: IVA.

Felstead, A., Fuller, A., Unwin, L., Ashton, D., Butler, P., \& Lee, T. (2005). Surveying the scene: Learning metaphors, survey design and the workplace context. Journal of Education and Work, 18(4), 359-383.

Fong, P. S., \& Chu, L. (2006). Exploratory study of knowledge sharing in contracting companies: a sociotechnical perspective. Journal of construction engineering and management, 132(9), 928-939. 
Fugate, M., Kinicki, A. J., \& Ashforth, B. E. (2004). Employability: a psycho-social construct, its dimensions, and applications. Journal of Vocational Behavior, 65(1), 14-38.

Gaspersz, J., \& Ott, M. (1996). Management van employability: nieuwe kansen in arbeidsrelaties [Management of employability: new chances in labor relationships]. Assen: Van Gorcum.

Geijsel, F. P., Sleegers, P. J. C., Stoel, R. D., \& Krüger, M. L. (2009). The effect of teacher psychological and school organizational and leadership factors on teachers' professional learning in Dutch schools. The Elementary School Journal, 109(4), 406-427.

Geijsel, F., Sleegers, P., Van den Berg, R., Kelchtermans, G. (2001). Conditions fostering the implementation of large-scale innovation programs in schools: teachers' perspectives. Educational Administration Quarterly, 37(1), 130-166.

Grangeat, M., \& Gray, P. (2007). Factors influencing teachers' professional competence development. Journal of Vocational Education and Training, 59(4), 485-501.

Grenier, R. S. \& Kehrhahn, M. (2008). Toward an integrated model of expertise redevelopment and its implications for HRD. Human Resource Development Review, 7(2), 198-217.

Griffiths, A. (1997). Ageing, health and productivity: a challenge for the new millennium. Work \& Stress, 11(3), 197-214.

Hill, R. \& Stewart, J. (2000). Human resource development in small organizations. Journal of European Industrial Training, 24 (2/3/4), 105-117. 
Hodkinson, H., \& Hodkinson, P. (2005). Improving schoolteachers' workplace learning. Research Papers in Education, 20(2), 109-131.

Hodkinson, P., \& Hodkinson, H. (2003). Individuals, communities of practice and the policy context: school teachers' learning in their workplace. Studies in Continuing Education, 25(1), 3-21.

Hoekstra, A. (2007). Experienced teachers' informal learning in the workplace. Doctoral dissertation, Utrecht: IVLOS Institute of Education of Utrecht University.

House, J. S. (1981). Work stress and social support. Reading, MA: Addison Wesley.

Hoyle, E., \& John, P. D. (1995). Professional knowledge and professional practice. London: Cassell.

Ilmarinen, J. (2005). Towards a longer worklife! Ageing and the quality of worklife in the European Union. Helsinki: Finish Institute of Occupational Health and the Ministry of Social Affairs and Health.

Johnson, B., \& Stevens, J. J. (2006). Student achievement and elementary teachers' perceptions of school climate. Learning Environments Research, 9(2), 111-122.

Jorgensen, B. (2004). Individual and organizational learning: a model for reform for public organizations. Foresight, 6(2), 91-103, 
Karasek, R. A. (1979). Job demands, job decision latitude, and mental strain: implications for job redesign. Administrative Science Quarterly, 24(2), 285-308.

Karasek, R. A., \& Theorell, T. (1990). Healthy work: Stress, productivity and the reconstruction of working life. New York: Basic Books.

Karsten, S., \& Meijer, J. (1999). School-based management in the Netherlands: The educational consequences of lump-sum funding. Educational Policy, 13(3), 421-439.

Klarenberg, K., Moorsel, M. van, \& Poell, R. (1996). Leerklimaat op de werkplek: Op zoek naar een meetinstrument [Learning climate at the workplace: In search for a measurement instrument]. Opleiding \& Ontwikkeling, 9(7/8), 22-27.

Krishnan, V. R. (2005). Transformational leadership and outcomes: role of relationship duration. Leadership \& Organization Development Journal, 26(6), 442-457.

Kwakman, K. (1998). Professional learning on the job of Dutch secondary teachers: in search of relevant factors. Journal of In-Service Education, 24(1), 57-71.

Kwakman, K. (1999). Leren van docenten tijdens de beroepsloopbaan [Teacher learning throughout the career]. Unpublished doctoral dissertation, University of Nijmegen, the Netherlands.

Kwakman, K. (2001). Work stress and work-based learning in secondary education: Testing the Karasek model. Human Resource Development International, 4(4), 487-501. 
Kwakman, K. (2003). Factors affecting teachers' participation in professional learning activities. Teaching and Teacher Education, 19(2), 149-170.

Lee, T., Fuller, A., Ashton, D., Butler, P., Felstead, A., Unwin, L., \& Walters, S. (2004). Workplace learning: main themes \& perspectives (Report No. 2). Leicester, UK: University of Leicester.

Loup, K. S. (1997). Measuring the professional learning environment of schools: linkages to school effectiveness and effects. International Journal of Educational Research, 27(4), 321-331.

Marsick, V. J., \& Watkins, K. E. (2001). Informal and incidental learning. New Directions for Adult and Continuing Education, 89, 25-34.

Martens, R. (2009). Succesvol leven lang leren op de werkplek. Onderzoek naar de praktijk van docentprofessionalisering [Successful lifelong learning at the workplace. Researching the practice of teachers' professional development]. Heerlen: Open University of the Netherlands.

Maurer, T. J. (2002). Employee learning and development orientation: Toward an integrative model of involvement in continuous learning. Human Resource Development Review, 1(1), 9-44.

McGuire, D., Cseh, M. (2006). The development of the field of HRD: a Delphi study. Journal of European Industrial Training, 30(8), 653-667. 
Mikkelsen, A. \& Grønhaug, K. (1999). Measuring organizational learning climate. A cross-national replication and instrument validation study among public sector employees. Review of public personnel administration, 19, 31-44.

Mintzberg, H. (1979). The structuring of organisations. A synthesis of the research. Englewood Cliffs, Prentice Hall Inc.

Murphy, C. \& Cross, C. (2006). The motivation of nurses to participate in continuing professional education in Ireland. Journal of European Industrial Training, 30(5), 365-384.

Nir, A. E., \& Bogler, R. (2008). The antecedents of teacher satisfaction with professional development programs. Teaching and Teacher Education, 24, 377-386.

Peeters, M. C. W., \& Le Blanc, P. M. (2001). Towards a match between job demands and sources of social support: A study among oncology care providers. European Journal of Work and Organizational Psychology, 10(1), 53-72.

Pillay, H., Kelly, K., Tones, M. (2010). Transitional employment aspirations for bridging retirement: Implications for training and development. Journal of European Industrial Training, 34(1), 70-86.

Poell, R. F., van Dam, K., van den Berg, P. T. (2004). Organising Learning in Work Contexts. Applied Psychology: An International Review, 53(4), 529-540. 
Pont, B., Nusche, D., \& Moorman, H. (2008). Improving school leadership, Volume 1: Policy and practice. Paris: OECD.

Putnam, R., \& Borko, H. (2000). What do new views of knowledge and thinking have to say about research on teacher learning? Educational Researcher, 21(1), 4-15.

Rosenholtz, S. J., Bassler, O., \& Hoover-Dempsey, K. (1986). Organizational conditions of teacher learning. Teaching \& Teacher Education, 2(2), 91-104.

Rothwell, A., \& Arnold, J. (2007). Self-perceived employability: development and validation of a scale. Personnel Review, 36(1), 23-41.

Runhaar, P. (2008). Promoting Teachers' Professional Development. Unpublished doctoral dissertation, University of Twente, the Netherlands.

Sahlstein, E., \& Duck, S. (2001). Interpersonal Relations. In W. P. Robinson \& H. Giles (Eds.), The new handbook of language and social psychology (pp. 371-382). Chichester, England: John Wiley \& Sons, Inc.

Sambrook, S. (2005). Factors influencing the context and process of work-related learning: synthesizing findings from two research projects. Human Resource Development International, 8(1), 101-119.

Schein, E. (1985). Organizational culture and leadership: a dynamic view. San Francisco: Jossey Bass. 
Scribner, J. P. (1999). Professional development: Untangling the influence of work context on teacher learning. Educational Administration Quarterly, 35(2), 238-266.

Shultz, K. S., \& Adams, G. A. (2007). Aging and Work in the $21^{\text {st }}$ Century. Mahwah, New Jersey: Lawrence Erlbaum.

Stoll, L., Bolam, R., McMahon, A., Wallace, M., \& Thomas, S. (2006). Professional learning communities: a review of the literature. Journal of Educational Change, 7, 221-258.

Taris, T. W., \& Feij, J. A. (2004). Learning and strain among newcomers: a three-wave study on the effects of job demands and job control. The Journal of Psychology, 138(6), 543-563.

Taris, T. W., \& Schreurs, P. J. G. (2009). Explaining worker strain and learning: how important are emotional job demands? Anxiety, Stress \& Coping, 22(3), 245-262.

Tsai, W. C., Chen, H. W., \& Cheng, J. W. (2009). Employee positive moods as a mediator linking transformational leadership and employee work outcomes. The International Journal of Human Resource Management, 20(1), 206-219.

Tschannen-Moran M. (2001). Collaboration and the need for trust. Journal of Educational Administration, 39(4), 308-331. 
Van Dalen, H. P., Henkens, C. J. I. M., Schippers, J. (2008). De lange mars van besef naar beleid: werkgevers en (hun) oudere werknemers [The long march from understanding to policy: employers and (their) older employees]. Tijdschrift voor HRM, 12, 40-62.

Van der Heijde, C.M., \& Van der Heijden, B.I.J.M. (2006). A competence-based and multidimensional operationalization and measurement of employability. Human Resource Management, 45, 449-476.

Van der Heijden, B. I. J. M. (1996). Life-long expertise development: goal of the nineties. Book of Proceedings of the Fifth Conference on International Human Resource Management. Hyatt Islandia San Diego, California, USA, 24-28 June, 1996.

Van der Heijden, B. I. J. M. (1998). The measurement and development of occupational expertise throughout the career. A retrospective study among higher level Dutch professionals. Unpublished doctoral dissertation, University of Twente, the Netherlands.

Van der Heijden, B. I. J. M. (2000). The development and psychometric evaluation of a multidimensional measurement instrument of professional expertise. High Ability Studies, 11(1), 9-39.

Van der Heijden, B. I. J. M. (2001). Encouraging professional development in small and mediumsized firms. The influence of career history and job content. Career Development International, $6(2 \& 3), 156-168$. 
Van der Heijden, B. I. J. M. (2002). Organizational influences upon the development of professional expertise in SME's. Journal of Enterprising Culture, 9(4), 367-406.

Van der Heijden, B. I. J. M. (2003). Organizational influences upon the development of occupational expertise throughout the career. International Journal of Training and Development, 7(3), $142-165$.

Van der Heijden, B. I. J. M., \& Bakker, A. A. (in press). Towards a model of employability enhancement. Journal of Career Development.

Van der Heijden, B. I. J. M., De Lange, Demerouti, E., \& Van der Heijde, C.M. (2009).

Employability and Career Success Across the Life-Span. Age Effects on the EmployabilityCareer Success Relationship. Journal of Vocational Behavior, 74, 156-164.

Van der Heijden, B. I. J. M., Demerouti, E., Bakker, A. B., \& Hasselhorn, H-M. (2008). Work-home interference among nurses: reciprocal relationships with job demands and health. Journal of Advanced Nursing, 62(5), 572-584.

Van der Heijden, B.I.J.M., Scholarios, D., Bozionelos, N., Van der Heijden, C.M., Epitropaki, O., \& the Indic@tor consortium (2005). Report on final results. Indic@tor Report: A cross-cultural study on the measurement and enhancement of employability in small and medium-sized ICT-companies. Brussels: European Commission. See: www.indicator-ict.com

Van Eekelen, I. (2005). Teachers' will and way to learn. Doctoral dissertation, Maastricht: University of Maastricht. 
Van Vegchel, N., De Jonge, J., Meijer, T., \& Hamers, J. P. H. (2001). Different effort constructs and effort-reward imbalance: effects on employee well-being in ancillary health care workers. Journal of Advanced Nursing, 34(1), 128-136.

Van Woerkom, M. (2003). Critical reflection at work. Bridging individual and organisational learning. Unpublished doctoral dissertation, University of Twente, the Netherlands.

Van Woerkom, M., Nijhof, W.J., \& Nieuwenhuis, L.F.M. (2002). Critical reflective working behaviour: a survey research. Journal of European Industrial Training, 26(8), 375-383.

Vermeulen, M. (1997). De school als arbeidsorganisatie. Doctoral dissertation, De Lier: ABC.

Wang, G. G., \& Wang, J. (2004). Toward a theory of human resource development learning participation. Human Resource Development Review, 3(4), 326-353.

Whittington, J. L., Goodwin, V. L., Murray, B. (2004). Transformational leadership, goal difficulty, and job design: independent and interactive effects on employee outcomes. The leadership quarterly, 15, 593-606. 
Figure 1. Baseline Conceptual Model 


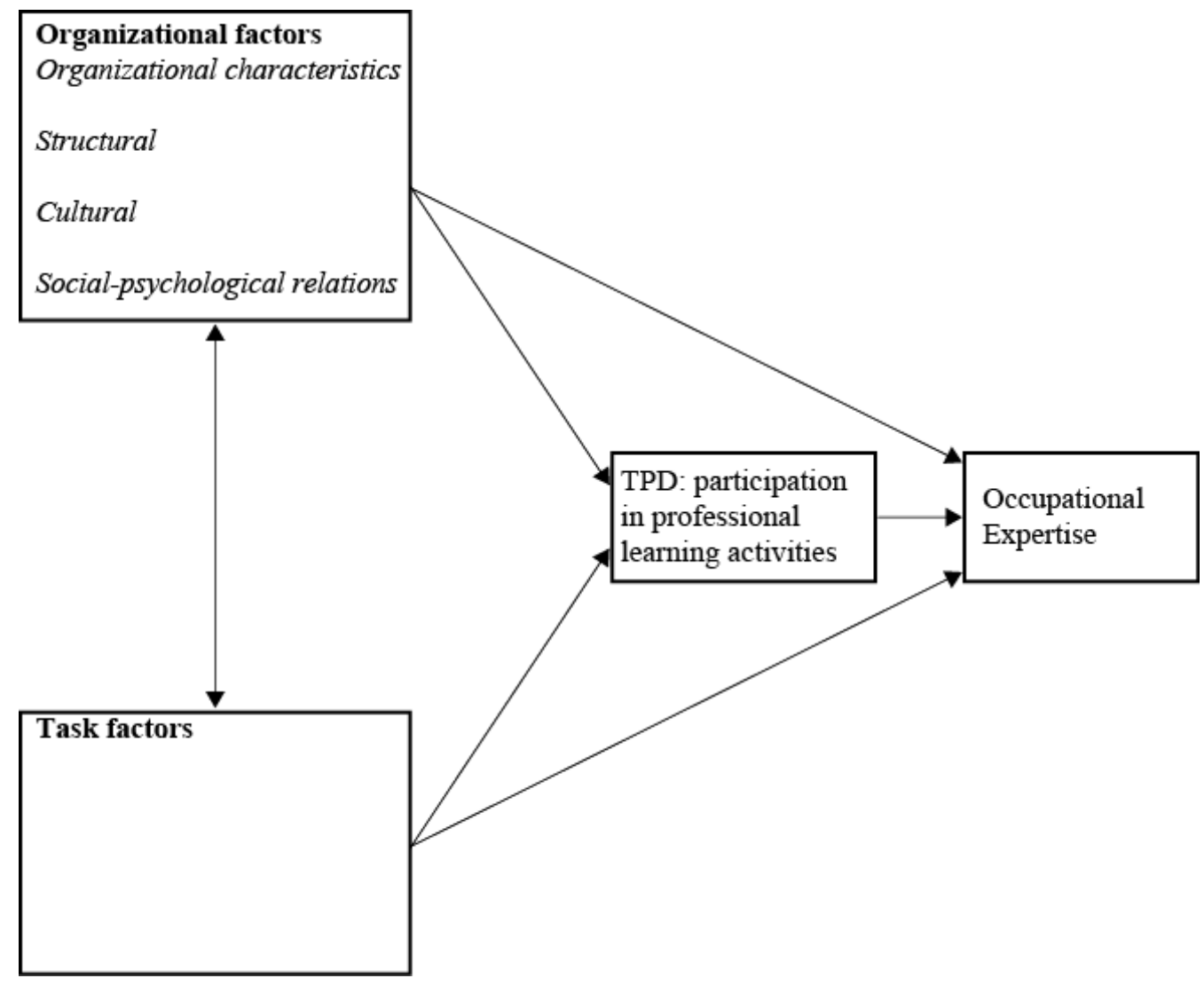


Figure 2. Conceptual model by Van Woerkom (2003) 


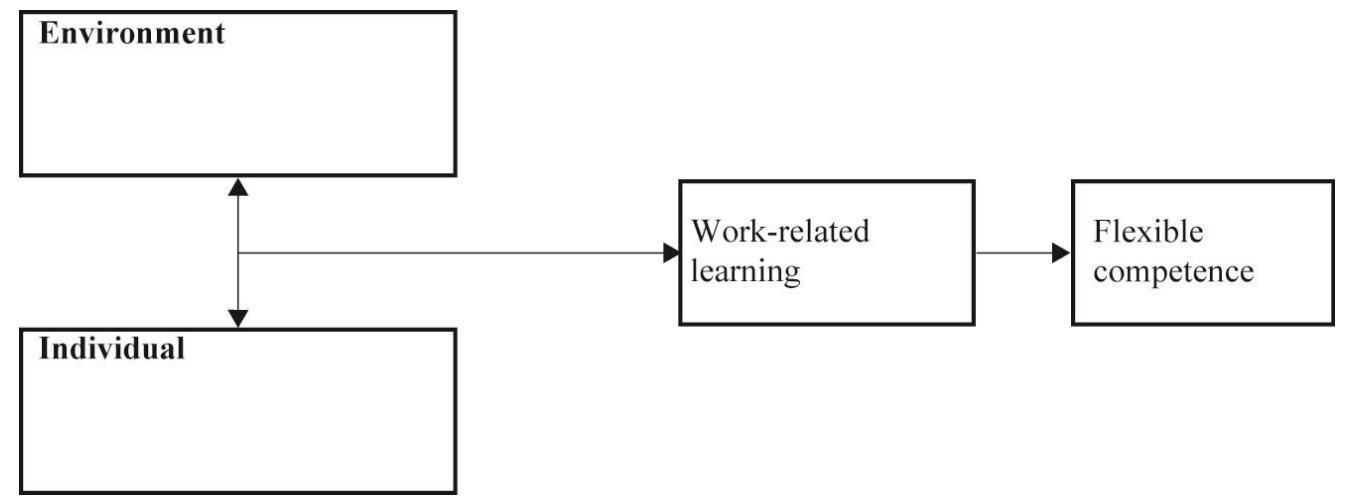


Figure 3. Summary of the relevant factors and their relationships in the TPD \& occupational expertise-model 


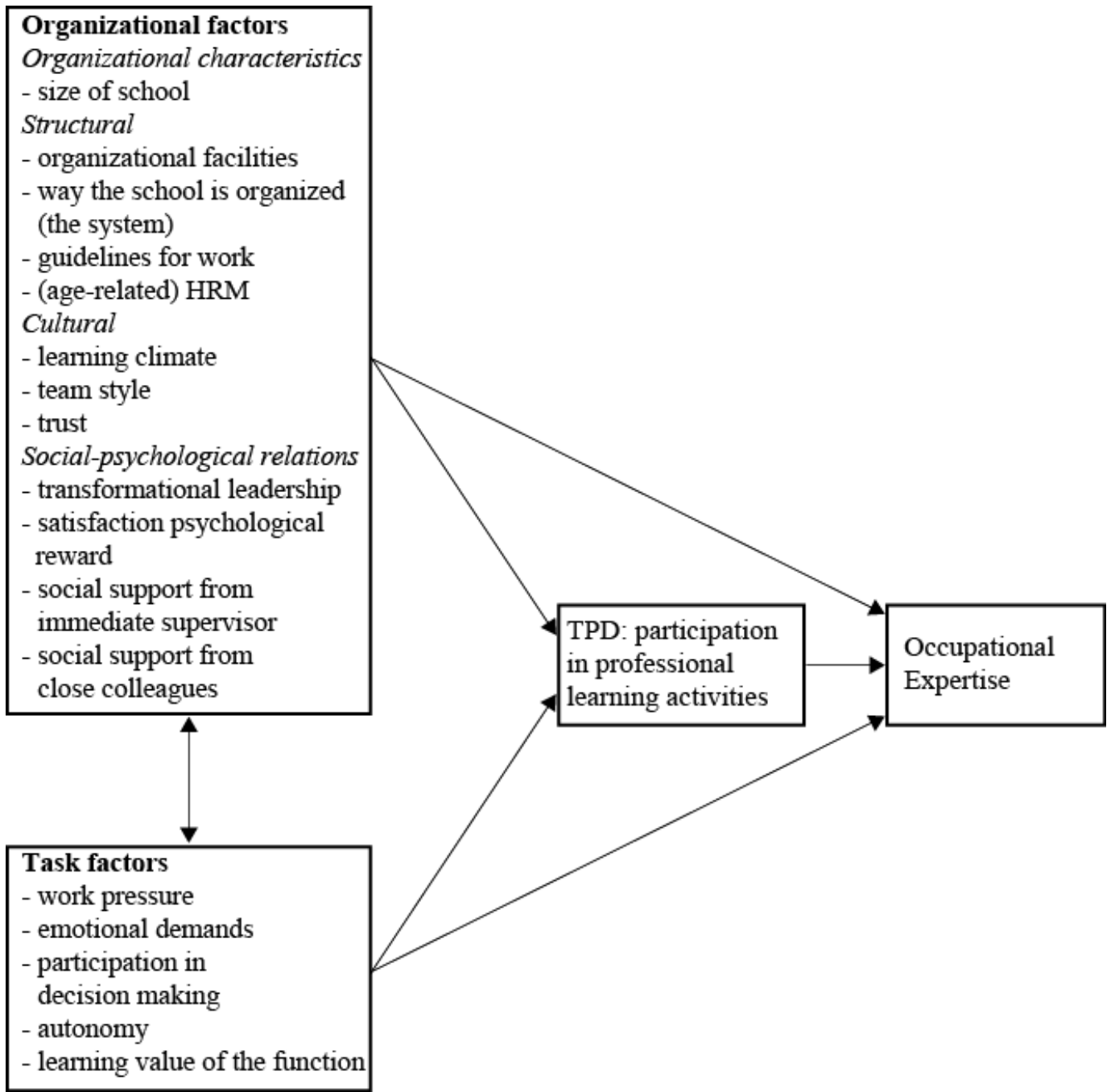


Figure 4. The TPD \& occupational expertise-model: hypothesizing that organizational and task predictors of occupational expertise are mediated by TPD 


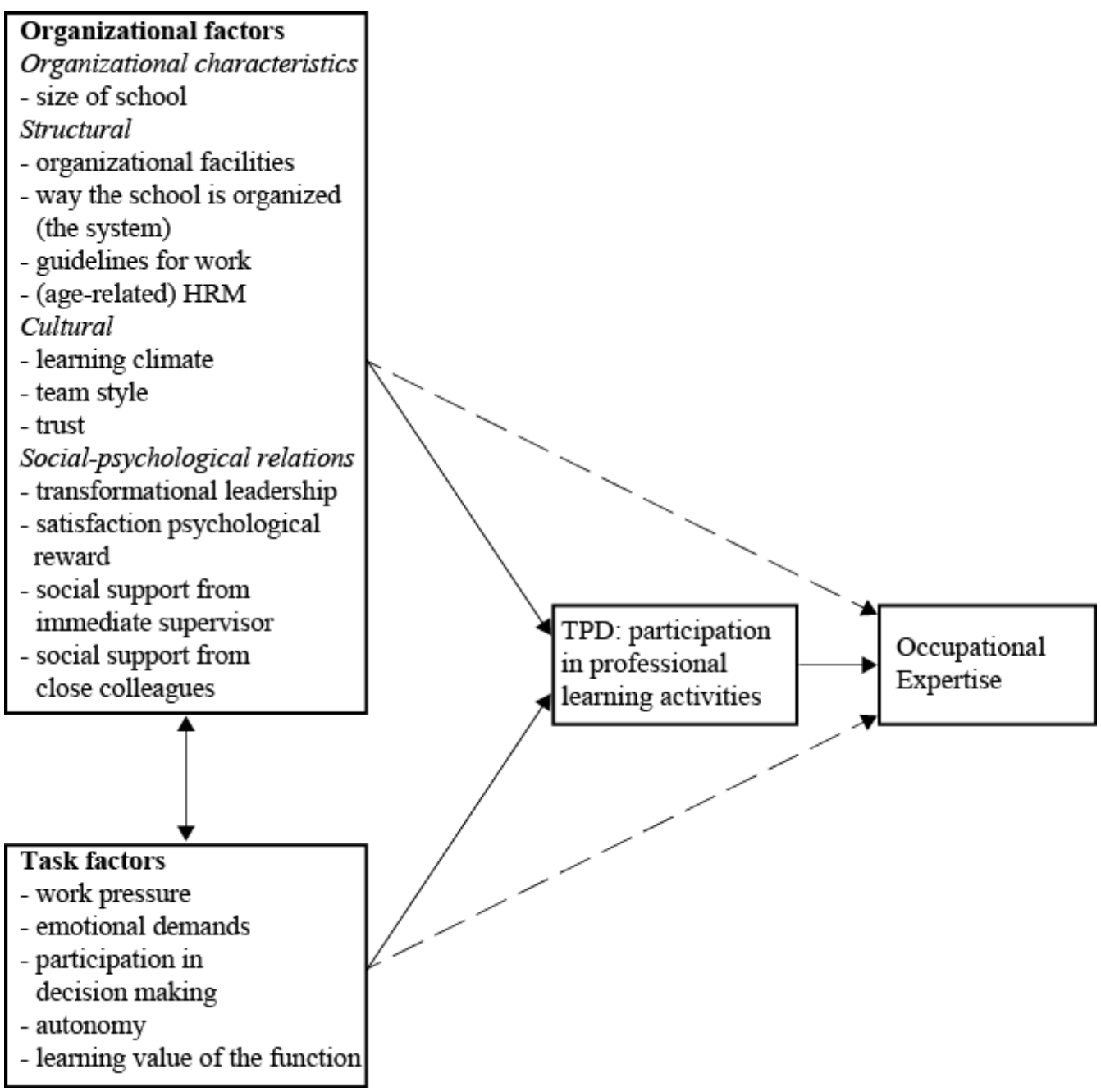

